\title{
Integrated Geological Resources Management for Public Lands: A Template from Yellowstone National Park
}

Paul K. Doss, Geology and Physics, University of Southern Indiana, Evansville, Indiana 47712, USA; pdoss@usi.edu

\begin{abstract}
Geological resources are often a neglected component of comprehensive natural resource management programs, and yet, all ecosystems are built upon the physical or abiotic foundation of the landscape. Geological resources pose hazards and create technical challenges while also providing both irreplaceable ecosystem functions and significant education. Our valuable geological resources are also invaluable indicators of environmental change. It is critically important that geological resource management be a central component of a comprehensive natural resource management plan.

Public lands account for nearly a third of the land area in the United States, but most public land management agencies do not have sufficient geological expertise on staff; external geoscientists complete much of the geological research and study on public lands. The effort to integrate geological resources into natural resource management, and the shortage of geological expertise within public land management staff, indicate the need for a widely applicable template for framing geological resource management. A functional structure is proposed for a comprehensive geological resource management program that can be adapted to a wide variety of public land administration scenarios. Specific examples from Yellowstone National Park show the importance of geological resource considerations in planning, construction, education, protection, hazard mitigation, and other activities. This paper also serves as a call for involvement by the larger geological community to address society's need for comprehensive geological resource management to be more fully integrated into natural resource management on our public lands.
\end{abstract}

\section{INTRODUCTION}

Natural resource management is often thought to be focused primarily on biological components of an ecosystem, and it is typically dominated by this focus. When geological resources are "managed," it is most likely for extraction purposes or hazard mitigation. "Management" of the environment or resources is also sometimes misconstrued to mean manipulation. Even in Flawn's Environmental Geology, he refers to the "honorable field of civil engineering" when discussing management of the "physical system" (Flawn, 1970, p. 191). Berger (1998) describes both national and international environmental reports that disregard abiotic components of ecosystems and their functional roles. Management considerations of geological resources are typically limited in scope to specifically address extraction of resources (e.g., fossil fuels), ecosystem restoration (e.g., the Everglades), environmental protection (e.g., soil erosion), resource protection (e.g., water resources), hazard mitigation (e.g., volcanic hazards), archaeology and paleoanthropology (e.g., prehistoric artifacts), and land-use planning (e.g., coastal zone management). A case has not been identified in which a comprehensive, fully integrated geological resources management plan has been developed for maintenance and protection of a public land resource base.

The United States government owns 655 million acresnearly $29 \%$ of the total U.S. land area (Vincent et al., 2001). State, county, and municipal governments hold additional lands. The U.S. Forest Service (USFS), Bureau of Land Management (BLM), National Park Service (NPS), and Fish and Wildlife Service (FWS) manage 96\% of federally owned land. Whereas extractive activity does occur on public land, national park lands are generally preserved.

External investigators from academia and other federal agencies perform much of the geological research and data collection on public lands. While federal service agencies such as the U.S. Geological Survey (USGS) are charged with providing the nation with reliable information for the management of geological resources, including extraction, the NPS, BLM, USFS, and FWS are distinctly land management agencies. As such, administrators of public lands must be responsible for the inventory, monitoring, and management of their geological resources, just as they are for management of biological and cultural resources. The direct and immediate relevance to the geological community is that most public land agencies and municipal governments do not have extensive geological expertise on staff; yet, comprehensive resource management must be grounded in the physical system. The NPS has clearly stated that "assistance from the broader geologic community is important to supporting park resource management" (National Park Service, 2006). Geological resources management is critically relevant for the integrity of entire ecosystems, for sensible resource use and protection, and for human safety.

Here I present the foundation of a geological resources management plan that was developed while I served as the supervisory geologist for Yellowstone National Park. For the purpose of this paper, the plan is presented in the form of a template, making it applicable for public land administration, land-use, and resource management situations. Moreover, this template could be modified to correspond to the typical divisions of local government entities to allow adoption within municipalities. My intent is to more comprehensively integrate geological resources into the traditional, biocentric natural resources management practices that are applied to public lands. This proposed integrated geological resources 
management plan offers a functional structure for understanding, managing, and protecting any unique geological environment. Examples from Yellowstone are cited, indicating the types of resources in need of protection as well as those that impact land-use planning and public land infrastructure. This draft plan benefited from review in peer forums (e.g., Doss, 2000, 2001a, 2002) and was presented in formal settings ranging from the Smithsonian Institution, USGS Headquarters, and at joint USGS/NPS workshops.

\section{DEFINING THE GEOLOGICAL RESOURCE BASE}

Geological resources comprise both features and processes. Features include stream channels, wetlands, geysers, and fossils. Processes might be groundwater flow, rockfalls, hydrothermal discharge, or erosion. Geological resource management should not inherently imply manipulation. Most large-scale geological processes cannot be aggressively changed, and in fact, the NPS is charged to "... allow geologic processes to proceed unimpeded" (National Park Service, 2000).
In Yellowstone National Park, the direct tangible influence of geological factors on total ecosystem function is readily observed (Fig. 1). Unique thermophile communities thrive in the varied hydrothermal discharges of the park. The seasonal migrations of ungulates, such as elk and bison, and consequently predators, are partly controlled by the high heat flow from the Yellowstone hotspot and the distribution of finegrained glacial deposits that retain moisture and support lush herbaceous growth through the dry season. Vertical movements of the Sour Creek resurgent dome at LeHardy Rapids alter Yellowstone Lake levels and disrupt spawning movements of native cutthroat trout in the Yellowstone River. Park visitation is periodically marred by hydrothermal fatalities and road closures from mass movements. While Yellowstone may be an exemplary "display case" for geological resources, every landscape and all public lands have unique geological resources and resource management concerns.

Geological processes operate on different time and spatial scales. In Yellowstone, geological processes relevant to resource
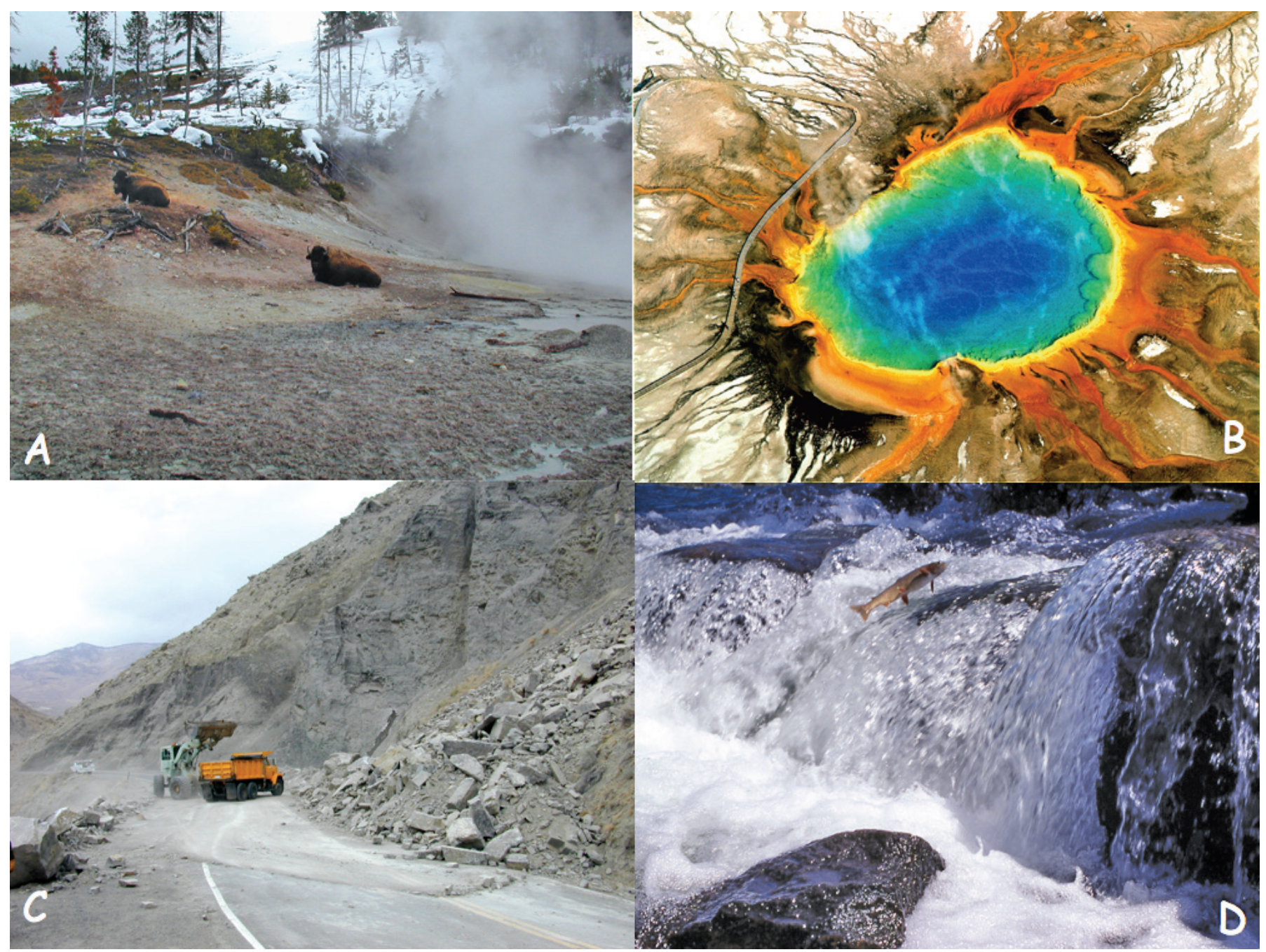

Figure 1. (A) Bison exploiting Yellowstone's high heat flow in the Mud Volcano area. Heat flow reduces snow pack, keeping food available year-round to ungulates living on the high altitude Yellowstone Plateau. (B) Colors in hydrothermal features such as Grand Prismatic Spring represent distinct thermophile communities thriving in waters of different temperatures. (C) Rockfall in Gardner Canyon closed the only year-round Yellowstone entrance road. (D) Cutthroat trout leaping the LeHardy Rapids along the Yellowstone River (National Park Service photo). LeHardy Rapids develops from uplift on the adjacent Sour Creek Resurgent Dome within the Yellowstone caldera. 


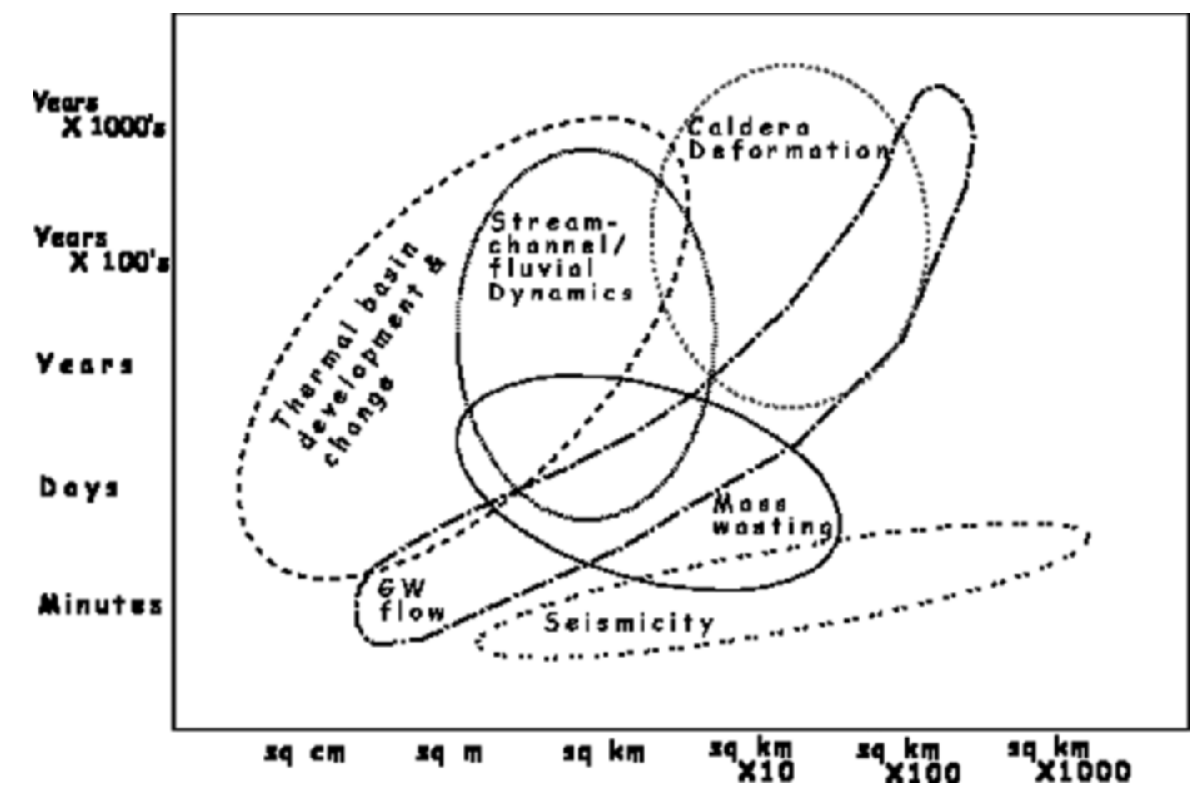

Figure 2. An approximation of the scale-rate relationship among several active geological processes in Yellowstone. Note that several of the processes converge on scales of less than a mile and less than a year.

management span temporal scales from seconds to thousands of years and spatial scales from centimeters to hundreds of kilometers (Fig. 2). Several of these dynamic processes converge on scales of less than a kilometer and less than a year. Visualizing geologic processes that operate on human time scales and within the boundaries of developed public lands may assist land managers in prioritizing management objectives. Every ecosystem includes geological features and processes that form "targets of management," including those that (1) are at risk of damage and theft (e.g., fossils); (2) pose inherent risks and hazards to visitors and staff (e.g., seismicity); and (3) demand close scrutiny relative to construction and infrastructure (e.g., mass movements).

Key to formulating resource management plans is an inventory of the geologic resources that need management oversight and of existing data and research results. It may be appropriate to first broadly characterize the resource base in order to facilitate development of such an inventory. In Yellowstone, 10 categories of geological resources have been identified (with representative research citations), including volcanic features and volcanism (Christiansen, 2001); landscapes, landforms, and glacial features (Shovic, 1996); lithological resources (Christiansen, 2001; Fritz, 1980); water quantity and quality (Farnes et al., 1999; Metesh et al., 1999; Elliott and Hektner, 2000; Marcus et al., 2001); hydrothermal features and discharge (Fournier et al., 1991; Johnson et al., 2003; Husen et al., 2004); mass movements (e.g., Wieczorek et al., 2000; Doss, 2001b); seismicity (Waite and Smith, 2004); caves (Barnosky, 1994); paleontological resources (Santucci, 1998); and soils (Rodman et al., 1996).

Of potential relevance to a land management agency, geoindicators are geological features and processes active near Earth's surface and on a human time frame that are high-resolution measures of change in ecosystem function, sustainability, and health (Berger, 1997). Analyses of geoindicators serve to identify environmental signals that might warn of impending change and help communicate that change to land managers and decision makers. Geoindicators can help focus a public land management plan on processes that are active on a human time frame and those that display the greatest likelihood of requiring immediate response. A description of individual geoindicators is not within the scope of this paper, but the NPS has adopted the geoindicator approach to implement some of its formal strategic planning goals (Higgins, 2000).

\section{REGULATORY FRAMEWORK FOR GEOLOGICAL RESOURCES MANAGEMENT}

Legal and regulatory mandates must frame and guide a geological resources management program on public lands and comprise federal and state legislation, contracts, and agency directives. The Wilderness Act of 1964 states that geologic features of scientific, educational, scenic, or historical value may be a defining attribute of wilderness areas. The National Environmental Policy Act of 1969 (NEPA), the basic national charter for environmental protection, is the policy of the federal government to "preserve important historic, cultural, and natural aspects of our national heritage." The Federal Cave Resources Protection Act of 1988 preserves significant caves on federal lands for use in scientific, educational, and recreational pursuits. The Federal Water Pollution Control Act (Clean Water Act of 1972) is designed to "restore and maintain the chemical, physical, and biological integrity of the Nation's waters." The NPS obtains and uses water for park purposes under the Reserved Water Rights and Prior Appropriation Doctrines. The Geothermal Steam Act of 1970 prohibits leasing of federally owned geothermal resources in all units of the National Park System, and the 1988 amendments to the act dictate that the "Secretary shall maintain a list of significant thermal features" and "shall maintain a monitoring program for significant thermal features." Where paleontological resources occur in an archaeological context, the Archaeological Resources Protection Act of 1979 provides protection.

NPS policy dictates that geologic resources will be preserved and protected as integral components of park natural systems (National Park Service, 2000). The NPS assesses the impacts of 


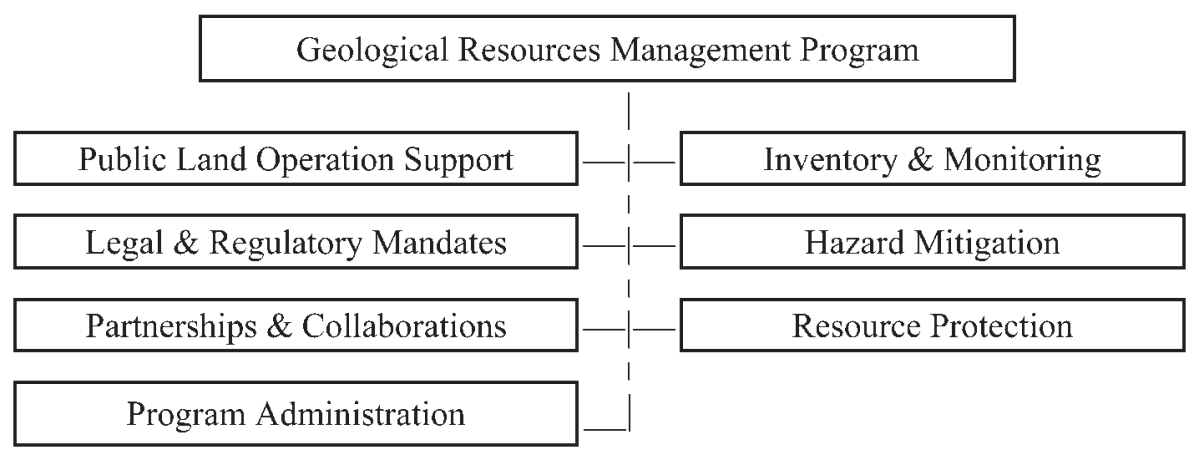

Figure 3. A proposed functional structure for a geological resources management plan for public lands. Functional divisions in this plan template can be applied to different public lands and through different management entities.

natural processes and human-related events on geologic resources, maintains and restores the integrity of existing geologic resources, integrates geologic resource management into NPS operations and planning, and interprets geologic resources for park visitors. Further, geologic processes are allowed to proceed unimpeded except when (1) directed by congress; (2) emergencies threaten life and property; (3) there is no other feasible way to protect natural resources, park facilities, or historic properties; or (4) necessary to restore impacted conditions and processes. Other geological resources in NPS guidelines include karst, geologic hazards, geologic features, paleontological resources and their contexts, caves, geothermal and hydrothermal resources, and soils. Specifically for Yellowstone, the Yellowstone Park Act of 1872 calls for “...the preservation from injury or spoliation of all timber, mineral deposits, natural curiosities, or wonders within said park, and their retention in their natural condition." Similar enabling legislation exists for most public lands.

\section{PROGRAM PRIORITIES, OBJECTIVES, AND STRUCTURE}

Management and operation of most public lands by a land management agency impact, or are impacted by, geological resources and processes in some way. A comprehensive resource management program must identify priority, sitespecific needs and must be responsive to land-use and regulatory demands. In most cases, priorities fall within the broad categories of hazard mitigation, resource use, resource protection, and education. Identified priorities can assist in the development of long-term program goals and strategies. The draft plan for Yellowstone lists four primary priorities. First, geological hazards to humans and infrastructure must be acknowledged and hazard mitigation plans developed. Second, the program must interact with all aspects of park operations to assure appropriate application of geological information to planning, construction, and mitigation, and must include measures to foster productive external collaborations. Third, the program must meet regulatory obligations for inventory of thermal features, development of hazard response plans, and administration of water rights compacts. Finally, the program should conduct regular and comprehensive outreach to park staff and visitors, particularly the interpretation division, to provide direct education and information regarding the dynamic nature of Yellowstone's geologic resources.
Broad objectives for a geological resources management program should be (1) active integration of geological knowledge into operations and planning; (2) facilitation and coordination of external geologic investigations directed at identification and mitigation of geologic hazards; (3) integration of geological knowledge throughout existing and proposed resource management programs; and (4) collaboration with external investigators in geological research as it relates to resource management.

In order to meet stated objectives, this geological resources management template is developed with a functional structure (Fig. 3). In contrast to a disciplinary or topical structure (e.g., by species in a biological resources program), a functional structure for program administration focuses on operational need as opposed to categories of operations. The need for a management program arises from three explicit observations and concerns: (1) the geologically related mandates placed upon the resource; (2) the needs of the various constituents of the public land operations; and (3) the dynamic nature of the geological features and processes on public land.

Development of a natural resource program based on a functional-operation standard offers many benefits. First, the program would be more responsive to immediate needs. Second, the program would be need-driven, as opposed to discipline-driven, and thus be better suited for development of programmatic vision resulting from systematic needs. Third, this type of program would have an appropriate level of overlap among divisions so that critical functions could be addressed within more than one area of concern (e.g., geological hazards can be addressed in inventory and monitoring, hazard mitigation, and resource protection). Finally, and perhaps most important, program personnel would not be restricted in duties and responsibilities by disciplinary labels. Staff will, by default, possess a disciplinary expertise, but the program and position responsibilities would be built around functional needs.

\section{PROGRAM FUNCTIONS}

\section{Support of Public Lands Operations}

In considering a functional approach to program implementation, a practical plan can use documented and observed needs from across a land management structure as an indicator for program development and as a realistic guide for operations. In addition, normal operations in other divisions may 
Table 1. List of divisions and primary responsibilities in Yellowstone National Park land management operations

\begin{tabular}{lc}
\hline \hline Operational Division & Primary Responsibility \\
$\begin{array}{l}\text { Resource Management } \\
\text { and Visitor Protection } \\
\text { Interpretation } \\
\text { Maintenance }\end{array}$ & $\begin{array}{c}\text { Law enforcement, visitor and staff safety, } \\
\text { visitors' services office } \\
\text { Public Affairs }\end{array}$ \\
$\begin{array}{l}\text { Public education, visitor center operations } \\
\text { Repair and rehabilitation of park infrastructure } \\
\text { Constituent relations, Freedom of Information } \\
\text { Act requests, press and media contacts }\end{array}$ \\
$\begin{array}{l}\text { Elanning } \\
\text { External contract management }\end{array}$ \\
$\begin{array}{l}\text { Yellowstone Center } \\
\text { for Resources }\end{array}$ & environmental assessments, compliance \\
\end{tabular}

benefit a geology program. The land management staff in Yellowstone is organized into seven broad divisions (Table 1). Each of these divisions has a mission and set of responsibilities, but, as is true of any complex organization, there are areas of shared responsibility. Most public lands and municipalities have analogous divisions of responsibilities. What follows are examples of the integration of geological resources management with the various park operation divisions at Yellowstone.

Division of Resource Management and Visitor Protection

Collaborative work with resource management and visitor protection staff includes forensics related to hydrothermal hazards (geological evidence collection), discussions of signage for hazards, and investigations of resource theft involving geological materials such as sinter and travertine. In one case, an individual was advertising a sample of travertine from Yellowstone for sale on a well-known Internet auction house. The resource management staff is directly involved with mitigation and/or remediation of resource damage such as that caused by visitor use, vehicle accidents, fuel spillage and pipeline damage, and impacts caused by planned construction. Division staff also offer assistance to geological resource management by collection of snow-water equivalence data from snow survey sites and with water rights issues such as monitoring irrigation withdrawals. Incidents include enhanced erosion near streamside pullouts, hydrothermal fatalities, diesel spills in alluvial sediments, and sewage spills from damaged infrastructure (Fig. 4).

\section{Interpretation and Concessions}

Interpretive staff need geological expertise for seasonal interpreter training, editing and preparation of trail guides, reviews of books under consideration for sale in visitor centers, conceptual planning for new educational video productions, and modifications to geological exhibits in visitor centers and wayside exhibits. As new geological research in parks leads to new conclusions, interpretations, and insight, interpreters and educators must be updated. Doss and Doss (1995) proposed the reasoning behind, methods for, and benefits of facilitating knowledge transfer in national parks. It is clear that all constituents, including educators, researchers, land managers, and the public, benefit from the active engagement of earth scientists with interpreters and other land management staff. Concessioners (tour guides) involved in programming and interpretation of natural resources for the public also require training on local geological resources.

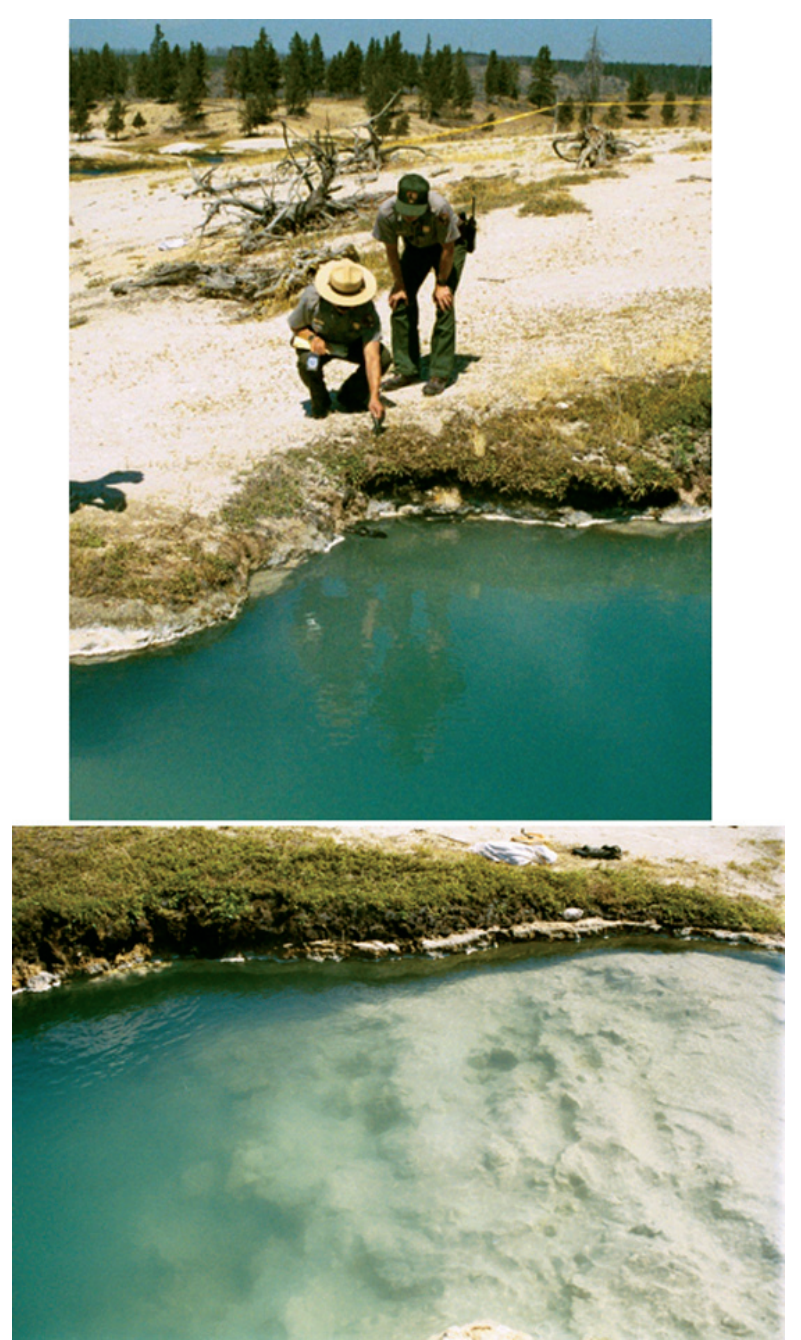

Figure 4. National Park Service geology and visitor protection staff investigating a backcountry hydrothermal accident site (note sandals in hot spring). Geologists mapped sediment disturbances (footprints-lower photo) in hot spring floor to assist in accident reconstruction.

\section{Planning and Public Affairs}

The planning office prepares construction designs and standards for park projects and prepares environmental assessments for NEPA compliance in construction and renovation projects, all requiring geotechnical assistance. Public affairs personnel need a "point of contact" for press and media inquiries regarding geological resources. Geology program staff accompany film crews and photographers seeking access to sensitive or dangerous thermal areas and also prepare briefing statements and press releases on geological issues.

\section{Maintenance}

The maintenance division is involved in maintaining, upgrading, monitoring, and construction of park infrastructure. In many cases, those activities require geotechnical investigations and information regarding slope and substrate stability and properties. Maintenance staff conduct systematic monitoring, such as roadbed condition, slope stability, and groundwater quality associated with water treatment facilities. Maintenance is also often the "first responder" to crisis incidents such as hazardous fluid spills and rockfalls. 
Table 2. Geological resources posing hazards or in need of protection in Yellowstone National Park*

\begin{tabular}{l}
\hline Hazards \\
Hydrothermal explosions \\
Large-magnitude seismicity \\
Mass movements \\
Other hydrothermal hazards \\
Subsidence \\
Erosion \\
Volcanic eruptions \\
Require Protection \\
Water quantity \\
Water quality \\
Paleontological resources \\
Hydrothermal features \\
Yellowstone Lake features \\
Caves \\
Lithologic resources \\
obsidian, sinter, petrified wood, travertine \\
Soils \\
Type sections \\
\hline *Resources that define priority inventory and \\
monitoring needs.
\end{tabular}

\section{Yellowstone Center for Resources}

Geological knowledge should be incorporated within the plans and projects of other natural and cultural resource programs. The geology program provides tangible assistance to the fisheries program by evaluating sediment transport, erosion, and stream channel dynamics adjacent to a fish-monitoring weir. High-resolution Yellowstone Lake bathymetry generated by cooperative USGS research (e.g., Morgan et al., 2007) also greatly benefits the fisheries program in their efforts to eradicate the invasive and detrimental lake trout illegally introduced into Yellowstone Lake. The program consulted on sediment transport studies in rivers and water-quality monitoring throughout the park and provided the vegetation management program with geological and soils information for a study of vegetation in the Absaroka volcanic terrane. Cultural resource programs have needs related to evaluation of geological history, sediment, source materials, and stratigraphic setting of archaeological resources, and investigation of the potential use of natural geological materials (mud, rocks, hot springs) in ceremonial events and customs.

\section{Geologic Hazard Mitigation}

The mitigation, where feasible, of geological hazards must be a priority for a geological resources management program (Table 2). While the NPS allows geological processes to operate unimpeded, steps can be taken to reduce hazards on public lands. The management program must include directives to identify specific locations where events might pose the greatest risk and attempt to forecast when, at what rate, and at what magnitude these events might occur (Fig. 5). In addition, the program should work directly with external collaborators to facilitate projects aimed at identifying and mapping hazard areas. Priority hazards in Yellowstone likely include hydrothermal explosion events, large-magnitude seismicity, and mass movements in developed or front-country areas.

\section{Geologic Resource Protection}

Geological resources in need of protection include those that are sensitive, rare, or commercially valuable (Fig. 6; Table 2). Efforts to protect these resources include comprehensive inventory compilations (e.g., Santucci et al., 2001). A geology program should benefit all appropriate divisions on issues of theft investigation, signage, trail construction and routing, protection and closure areas, and Freedom of Information Act restrictions, where appropriate, for the protection of these resources. For

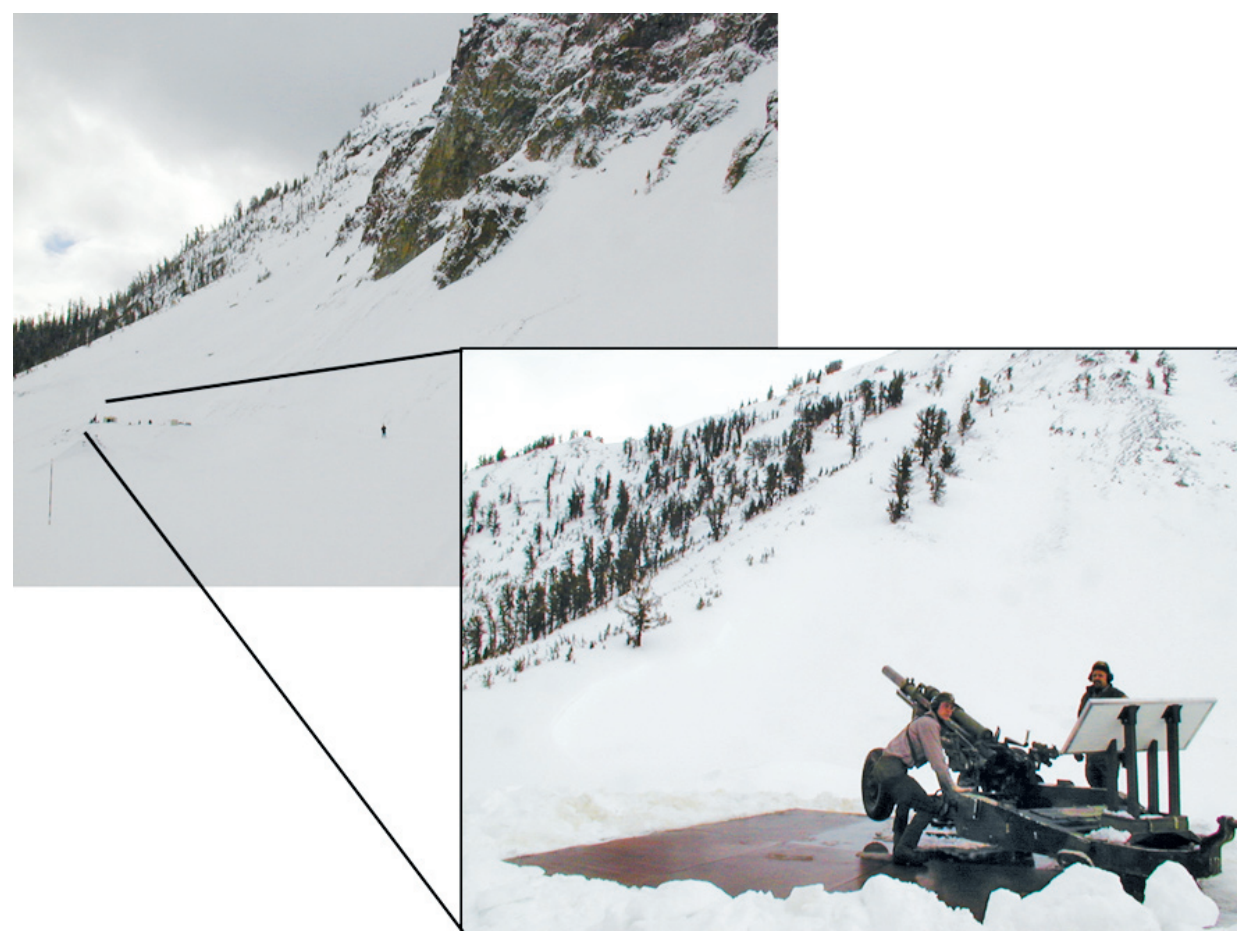

Figure 5. Avalanche control along the East Entrance road at Sylvan Pass utilizes a WWIIera Howitzer. The gun site sits at the base of a nearly vertical, >1000-ft (300-m) exposure of the Eocene Absaroka Volcanics. Firing and detonation blasts during avalanche control periodically generated rockfalls that put National Park Service staff at risk. 


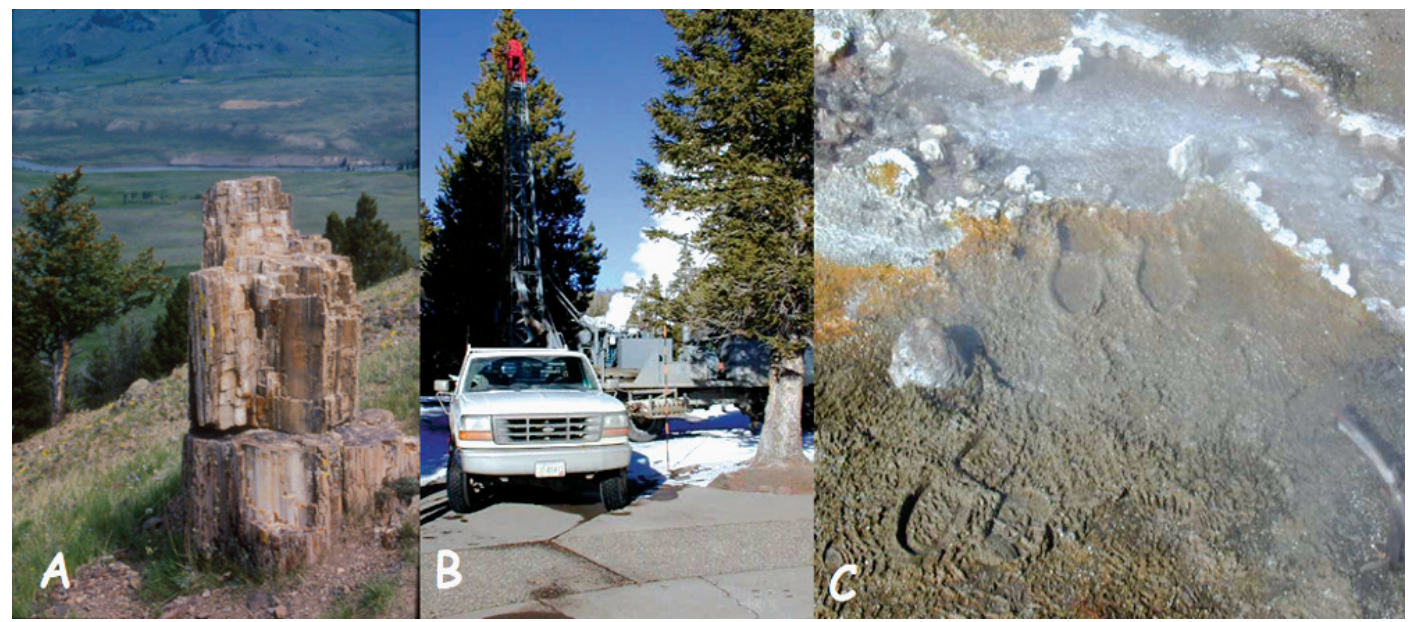

Figure 6. Geological resources in need of protection include rare or valuable materials and geological processes. (A) One of the many in situ petrified stumps found within the Eocene Absaroka Volcanic deposits. (B) Geotechnical drilling in close proximity to an erupting Old Faithful geyser in preparation for new Visitor Center planning and construction. (C) Sinter damaged by foot traffic along a thermal runoff channel near a historically significant hot spring.

example, many public lands contain stratigraphic type sections that should be inventoried for their protection because type sections can represent an important historical resource.

\section{Legal and Other Mandates}

Mandates form a critical functional component of any resource management program. Federal, state, local, and agency-specific mandates upon the NPS and other specific land units require land managers to address the applicable resource management concerns. In addition, the USGS is federally mandated under the Stafford Act (Public Law 93-288) to issue timely warnings of potential geologic disasters in the United States to the affected populace and civil authorities. This mandate to USGS applies to all lands.

\section{Partnerships and External Collaborations}

The USGS carries out part of its Stafford Act responsibility with the Volcano Hazards Program. This mandate upon the USGS was, in part, the motivation for development of the Yellowstone Volcano Observatory (YVO) in 2001. The YVO is aligned with the USGS Volcano Hazards Program in a similar manner to the Hawaii, Cascades, Long Valley, and Alaska Volcano Observatories. Yellowstone has a vested interest in the issuance of volcanic and seismic warnings, and as such, is positioned within the YVO to be an equal partner and coordinator in research direction, monitoring strategy, and hazard plan development. The geology program provides the Yellowstone National Park coordinating scientist for the YVO and participates in planning events and regular volcano activity updates.

Partnerships and collaborations are fundamentally important components of geological resources management programs on public lands. Morgan (2007) represents an excellent example of this collaboration in Yellowstone. On public lands, much of the geological work conducted over the past century has been part of an organized and integrated program administered by the USGS that comprises investigations from the geologic, water resources, and biological resources divisions. Other federal agencies involved in geological investigations on public lands include the USFS, the FWS, the Natural Resources Conservation Service, and NASA. In Yellowstone, state agency partners that participate in geologic investigations include the Montana Bureau of Mines and Geology, Montana Fish Wildlife and Parks, and the Wyoming Game and Fish Department. Numerous academic institutions have faculty and research per- sonnel who focus their efforts in Yellowstone National Park. The research permitting office in Yellowstone reviews permits for NEPA compliance, keeps categorized records of permit applications, and compiles annual investigator reports.

\section{Inventory and Monitoring}

Any public land is best served in its resource management initiatives when those resources are initially inventoried and subsequently monitored (Table 2). In many ways, the list of features for inventory mirrors the list of resources to be protected, and the inventory process is a means to develop an integrated database and a protection plan. A comprehensive inventory also provides a standard against which change can be measured and assessed, and an inventory of geological hazards is a prerequisite for hazards mitigation. A comprehensive inventory of all geological features in any specific area is likely impossible; however, those resources that may be most threatened (e.g., accessible by visitors, in areas of active surface processes, in areas of previous disturbance, or planned construction sites) should be priorities for inventory and monitoring.

In Yellowstone, inventories of hydrothermal features and thermophiles are ongoing, as are USGS stream gauging activities on Soda Butte Creek and the Lamar, Yellowstone, and Gardiner rivers, as well as snow course survey measurements of snowpack for runoff and moisture predictions. The YVO is coordinating seismic, regional GPS, some hydrothermal, and other monitoring efforts. The maintenance division regularly monitors water quality in the vicinity of treatment facilities, and those data can be invaluable for park-wide monitoring.

\section{Program Administration}

An important resource management program function is the conduct of "inreach," or education of peers and management on the justification, roles, and need for a geological resources management program. In many ways, the inreach of this program is accomplished by interactions during operations support.

Administration of any program includes program development, modification, and enhancement as needs warrant. A fully functional program will provide guidance, advice, and serve as a management tool that is, ideally, personnel-independent. The program must also result in the generation of initiatives and proposals that achieve program goals. Initiatives can include interdivisional partnerships and collaborations with external agencies and individual investigators. 


\section{SUMMARY}

Geological resources on public lands result from processes that have operated throughout geological history but remain active; impart challenges to park operations, management, and policy; pose risks to visitors and staff; and provide opportunities for education and interpretation. Public land managers have the obligation to be responsible for the inventory, monitoring, and management of geological resources in the same manner as they manage biological and cultural resources. Yet in many cases, the larger geological community is in the primary position of collecting the geological data and generating research results on public lands. The management of geological resources in our public lands is critically relevant for the integrity of all resources and ecosystems.

The functional structure of the proposed Geological Resources Management Program permits and encourages land managers to focus effort on operational need. It also encourages external geoscientists to interpret how their work may fit in the larger context of geological resources management. The availability of a functional geological resources management program aimed at understanding the diversity of geological features and processes will help assure the safety of visitors and staff, the appropriate use of our natural resources, the accurate education of visitors and staff, and a more thorough understanding of the magnificent resources preserved in our public lands.

\section{ACKNOWLEDGMENTS}

Many individuals have provided written information used in the preparation of the draft plan, including Ann Rodman, Vince Santucci, and Dr. Robert Smith. I thank John Varley, Wayne Brewster, Ann Deutch, Ann Rodman, Tom Olliff, Diane Chalfant, Bob Higgins, and the entire National Park Service staff for their help during my tenure at Yellowstone. My effort and time in the park was rewarding in large part because of some remarkable interactions with geologists like Lisa Morgan, Pat Shanks, Bob Christiansen, Ken Pierce, Marianne Guffanti, Bob Smith, and Duncan Foley. I also thank the University of Southern Indiana Pott College of Science and Engineering for its support and Tony Maria, Heidi Doss, and Stephen Johnston for their thoughtful reviews of this manuscript.

\section{REFERENCES CITED}

Barnosky, E.H., 1994, Ecosystem dynamics through the past 2000 years as revealed by fossil mammal from Lamar Cave in Yellowstone National Park: Historical Biology, v. 8, p. 71-90.

Berger, A.R., 1997, Assessing rapid environmental change using geoindicators: Environmental Geology, v. 32, p. 36-44, doi: 10.1007/s002540050191.

Berger, A.R., 1998, Environmental change, geoindicators, and the autonomy of nature: GSA Today, v. 8, no. 1, p. 3-8.

Christiansen, R.L., 2001, The Quaternary and Pliocene Yellowstone plateau volcanic field of Wyoming, Idaho, and Montana: U.S. Geological Survey Professional Paper 729-G, 143 p.

Doss, P.K., 2000, Geology at Yellowstone National Park, a new chapter: Geological Society of America Abstracts with Programs, v. 32, no. 7, p. 263.

Doss, P.K., 2001a, Yellowstone Lake as a microcosm of geological resources management at Yellowstone National Park: Yellowstone Lake—hotbed of chaos or reservoir of resilience?: Yellowstone National Park, Agenda and Abstracts, 6th Biennial Scientific Conference on the Greater Yellowstone Ecosystem, p. 43-44.

Doss, P.K., 2001b, Mass movements: An important geological process in Yellowstone: The Buffalo Chip, Resource Mgmt. Newsletter, April-May 2001, Yellowstone National Park, p. 1-3.

Doss, P.K., 2002, Geology and Geothermal Resources, in Yellowstone Center for Resources Annual Report, 2000: Mammoth Hot Springs, Wyoming, National Park Service YCR-AR-2000, p. 33-39.
Doss, P.K., and Doss, H.J., 1995, Enhanced earth science research and public education in the U.S. National Park System: GSA Today, v. 5, no. 11, p. 216-218.

Elliott, C.R., and Hektner, M.M., 2000, Wetland resources of Yellowstone National Park: Yellowstone National Park, 32 p.

Farnes, P., Heydon, C., and Hansen, K., 1999, Snowpack distribution across Yellowstone National Park: Bozeman, Montana, Dept. of Earth Sciences, Montana State Univ., Final Report to Yellowstone Center for Resources, Proposal no. 97-447, 58 p.

Flawn, P.T., 1970, Environmental geology: Conservation, land-use planning, and resource management: New York, Harper \& Row, 313 p.

Fournier, R.O., Thompson, J.M., Cunningham, C.G., and Hutchinson, R.A., 1991, Conditions leading to a recent small hydrothermal explosion at Yellowstone National Park: Geological Society of America Bulletin, v. 103, p. 11141120, doi: 10.1130/0016-7606(1991)103<1114:CLTARS>2.3.CO;2.

Fritz, W.J., 1980, Reinterpretation of the depositional environment of the Yellowstone "fossil forests": Geology, v. 8, p. 309-313, doi: 10.1130/00917613(1980)8<309:ROTDEO>2.0.CO;2.

Higgins, R.D., 2000, Geoindicators making connections to resource issues and research in the National Park Service: Geological Society of America: Abstracts with Programs, v. 32, no. 7, p. 294

Husen, S., Taylor, R., Smith, R.B., and Heasler, H., 2004, Changes in geyser eruption behavior and remotely triggered seismicity in Yellowstone National Park produced by the 2002 M 7.9 Denali Fault earthquake, Alaska: Geology, v. 32, p. 537-540, doi: 10.1130/G20381.1.

Johnson, S.Y., Stephenson, W.J., Morgan, L.A., Shanks, W.C., III, and Pierce, K.L., 2003, Hydrothermal and tectonic activity in northern Yellowstone Lake Wyoming: Geological Society of America Bulletin, v. 115, p. 954-971, doi: 10.1130/B25111.1.

Marcus, W.A., Meyer, G.A., and Nimmo, D.R., 2001, Geomorphic control of persistent mine impacts in a Yellowstone Park stream and implications for the recovery of fluvial systems: Geology, v. 29, p. 355-358, doi: 10.1130/00917613(2001)029<0355:GCOPMI>2.0.CO;2.

Metesh, J., English, A., Lonn, J., Kendy, E., and Parrett, C., 1999, Hydrogeology of the Upper Soda Butte Creek Basin, Montana: Report of Investigation 7, Montana Bureau of Mines and Geology, $66 \mathrm{p}$.

Morgan, L., editor, 2007, Integrated Geoscience Studies in the Greater Yellowstone Area-Volcanic, Tectonic, and Hydrothermal Processes in the Yellowstone Geoecosystem: U.S. Geological Survey Professional Paper 1717, 532 p.

Morgan, L., Shanks, W.C., Pierce, K.L., Lovalvo, D.A., Lee, G.K., Webring, M.W., Stephenson, W.J., Johnson, S.Y., Harlan, S.S., Schulze, B., and Finn, C.A., 2007, The floor of Yellowstone Lake is anything but quiet-New discoveries from high-resolution sonar imaging, seismic-reflection profiling, and submersible studies, in Morgan, L ed Integrated Geoscience Studies in the Greater Yellowstone Area-Volcanic, Tectonic, and Hydrothermal Processes in the Yellowstone Geoecosystem: U.S. Geological Survey Professional Paper 1717, p. 91-126.

National Park Service, 2000, Management Policies 2001: U.S. Department of the Interior, Washington, D.C., 123 p.

National Park Service, 2006, 2005 Geologic Resources Division Natural Resources Challenge Report: U.S. Department of the Interior, Washington, D.C., $17 \mathrm{p}$.

Rodman, A., Shovic, H., and Thomas, D., 1996, Soils of Yellowstone National Park: Yellowstone Center for Resources, Yellowstone National Park, Wyoming, YCR-NRSR-96-2, 324 p.

Santucci, V.L., 1998, Paleontological resources of Yellowstone National Park: Yellowstone Center for Resources, National Park Service, Yellowstone National Park, Wyoming, YCR-NR-98-1.

Santucci, V.L., Kenworthy, J., and Kerbo, R., 2001, An inventory of paleontological resources associated with National Park Service caves: National Park Service Geological Resources Division Technical Report, NPS/NRGRD/ GRDTR-01/02, 50 p.

Shovic, H., 1996, Landforms and associated surficial materials of Yellowstone National Park: Yellowstone Center for Resources, Yellowstone National Park, Wyoming, YCR-NRSR-96-3, $230 \mathrm{p}$.

Vincent, C.H., Cody, B.A., Corn, M.L., Gorte, R.W., Johnson, S.L., Whiteman, D., and Baldwin, P., 2001, Federal Land Management Agencies: Background on Land and Resource Management: Congressional Research Service, The Library of Congress, $71 \mathrm{p}$.

Waite, G.P., and Smith, R.B., 2004, Seismotectonics and stress field of the Yellowstone volcanic plateau from earthquake first-motions and other indicators: Journal of Geophysical Research, v. 109, B02301, doi: 10.1029/2003JB002675.

Wieczorek, G.F., Snyder, J.B., Waitt, R.B., Morrissey, M.M., Uhrhammer, R.A., Harp, E.L., Norris, R.D., Bursik, M.I., and Finewood, L.G., 2000, Unusual July 10, 1996, rock fall at Happy Isles, Yosemite National Park, California: Geological Society of America Bulletin: v. 112, p. 75-85, doi: 10.1130/00167606(2000)112<75:UJRFAH >2.0.CO;2. 